\title{
Defying Notions of Nineteenth Century Masculine Honour in the War of 1812: The Case of the American Burning of Newark, December 1813
}

\author{
By Amanda Balyk
}

Lieutenant William MacEwan wrote to his wife upon visiting Fort George in March of 1814 after seeing the aftermath of the burning of Newark that occurred on December $10^{\text {th }}, 1813$. He wrote, "The whole place is a ruin, nothing to be seen but brick chimneys standing, what the fire could not destroy, of the once beautiful town of Newark."1 Before that fateful winter night, in the summer of 1813, in the second year of the War of 1812 between the Americans and British/Canadians, Americans had gained serious momentum in the Niagara region by capturing the British Fort George. However, by December, winter was threatening the American position at Fort George, so American General George McClure decided that it would be best to abandon their post and return to the American Fort Niagara across the Niagara River. As historian George Sheppard notes, earlier in the year the American Secretary of State John Armstrong told McClure that "a successful defence of Fort George might require the destruction of the town of Niagara" and if McClure thought that destruction was necessary, that he would need to "apprise its inhabitants of these plans, giving them ample time to remove themselves and their belongings to a place of safety."2

However, when it came time to leave Fort George, this is not what occurred. On December $10^{\text {th }}$, McClure decided to abandon his post but decided burn the town down anyway and gave Col. Joseph Willcocks the responsibility of setting Newark ablaze. Although Armstrong had mentioned that burning Newark may be a necessary source of defence, on December $10^{\text {th }}$ McClure acted without direct orders to burn the town. In the previous month, General Harrison, in a letter to McClure, referred to Canadian turncoat Colonel Willcocks as an asset for the Americans in Niagara due his "zeal, activity and local knowledge."3 Subsequently under the leadership of Col. Willcocks, the town's population of 400 people were given half an hour to gather their belongings before 300 homes were set alight. ${ }^{4}$ Although the burning of Newark is noteworthy as it had serious implications for the displaced civilians, the burning was of further significance as it clearly challenged contemporary notions of masculine honour that were made clear in the War of 1812. Masculine honour cannot be described as a fixed concept as it was, and still is, constantly changing. However, there were specific rules of war that were expected of men, and the Newark case clearly set American men outside of these honourable 
norms. This paper evaluates the ways in which the Americans' burning of Newark challenged nineteenth-century notions of masculine honour in the War by first evaluating the expectations of men in war. Comparing these notions to reactions to the burning in contemporary print and communications between General McClure and Secretary Armstrong reveals a dichotomy between expectations of honour and the practice of "honour" as seen in the burning. Finally, this paper evaluates war losses claims to demonstrate the implications for civilians impacted by the burnings itself in order to further prove that the burning of Newark challenged nineteenthcentury notions of masculine honour for soldiers in the War.

Some historians have attempted to construct a cohesive understanding of what masculinity and honour meant during the War of 1812. Beginning with Robin Fabel's publication on the laws of the War of 1812, he claims there is a clear similarity between American and British codes of law in regards to how one should conduct himself in wartime. ${ }^{5}$ There is a clear onus on protection as a means for defining proper manly conduct. Fabel writes from a largely American perspective and notably mentions that the British committed various outrages in their conduct during the war, which included burning private houses. ${ }^{6}$ If this was considered an "outrage in conduct" when done by the British, of course, it should similarly be viewed as an outrage in conduct when done by Americans in Newark. He further notes that there was an understanding that "as soon as your enemy has laid down his arms and surrendered his person, you have no further rights over his life."7 By this standard, civilians should be implicitly synonymous with an enemy with no weapon as they were in no way attempting to threaten the other side and thus required some sense of protection. Indeed, that would mean that they had no rights over civilian life, which places the burning of Newark and the consequent displacement of over 400 people outside of the American laws of war during 1812.

This disobeying of laws of war brings up an important question. How does this relate to masculinity, and, specifically, despite the burning of Newark bringing up obvious moral questions, how does the burning of Newark challenge masculine honour? Leo Braudy claims that in the nineteenth century "the chivalric code had emphasized the vulnerable female body as an object for which men were ready to fight as part of their defence of civilized virtue." ${ }^{8}$ This suggestion of a chivalric code relying on protecting the vulnerable woman is seen in rhetoric used in recruitment advertisements in the war. This includes an advertisement in the Kingston Gazette in 1813, which stated "Sharp Shooters. Volunteers. Wanted for the Glengary Light 
Infantry Fencibles. - Brave and loyal young men of good character, who wish to defend their lives and property, their mothers and sisters from insult, their country from invasion and dishonour." This advertisement attempts to recruit men who wish to fulfil masculine notions and expectations of protecting women (mothers and sisters) and thus confirms the chivalric code that Braudy suggests. This code once again suggests that the burning of Newark challenged contemporary notions of masculinity and honour, as Prevost suggests that most of the 400 victims who lost their livelihood in the fire were women and children. Thus, the American soldiers effectively defied notions of masculine honour in that they did not protect females in the way that nineteenth-century chivalry suggested they should. Overall, Braudy's notion of nineteenth-century masculinity and honour acts as the basis for the ideals of masculine honour presented in this paper.

When there is a clear understanding of masculine and honourable expectations of soldiers during the war, the ways in which the burning of Newark challenged these masculine expectations can become stronger, especially when notions of masculine honour and the act itself are compared with the American response to the burnings. In the 31 May 1813 edition of The War, a published letter from McClure to Armstrong claimed:

the village of Newark is now in flames - the few remaining inhabitants in it, having been notified of our intention, were enable to remove their property. The houses were generally vacant long before. This step has not been take without council, and is in conformity with the views of your excellency, disclosed to me in former communication.

In his subsequent letter, McClure claimed, "every building in Newark is reduced to ashes."10 This rhetoric was meant to boast to Armstrong about events in Newark. McClure assures Armstrong that he acted in accordance to Armstrong's orders as they were outlined in his previous communications. He further ensures him that the "few remaining inhabitants" were notified with enough time to leave. He reiterates this in an address to the public attempting to justify his actions as defensive by claiming that it would be:

madness in the extreme to attempt to hold [Fort George], and recommended its evacuation immediately, as the enemy's advance was then within eight miles ... and ordered the town of Newark to be burnt. This act, however distressing to the inhabitants and my feelings, was by order of the Secretary at war, and I believe at the same time proper. The inhabitants 
had twelve hours' notice to remove their effects, and such as chose to come across the river were provided with all the necessaries of life. ${ }^{11}$

Again, McClure attempts to justify his actions by claiming they complied with honourable actions of men in war. He claims the burning was a response to the British approach on Fort George and that they followed the protocol to warn civilians before burning their homes. Therefore, McClure suggests that there was still a level of protection in his action in that he ensured that civilians were told of the plans with more than enough time to leave and seek shelter.

Interestingly, as mentioned, Sheppard points to contemporary documentation which claims that civilians were only given thirty minutes to get out of their homes, ${ }^{12}$ which suggests that McClure's claim of twelve hours was an attempt to justify his actions and make himself seem more honourable in the situation. McClure further positions Armstrong as the key decision maker behind the burning, attempting once again to justify his actions and offset the blame. If McClure's statement was considered alone, it could be assumed that the burning of Newark did not defy notions of honour in the war as he followed protocol that was outlined by his superior. However, when his statements are considered in relation to other documents, a clear contradiction emerges that suggests that McClure was not justified in his actions and worked distinctly outside of nineteenth-century notions of wartime masculinity and honour.

Armstrong himself addressed the burning of Newark in a letter to the Governor of New York Daniel Tompkins. He spoke to McClure's claims that he was behind the decision to burn Newark, completely discrediting them. He wrote, "McClure had not, (as you seem to suppose,) authority for doing anything he did ... He hints that Newark was burnt by my orders. This is a great error. My orders were to burn it if necessary to the defence of Fort George, not otherwise. But he does not defend Fort George, then burns Newark." ${ }^{\prime 3}$ This statement is significant as this clearly contrasts McClure's defense of the burning and discredits his statements claiming that he acted on the request of Armstrong himself. This statement coming from McClure's superior is significant as he clearly does not defend McClure's actions, and therefore, this suggests that the burning of Newark existed outside of the expectations that the American government had for its soldiers. What's more, by discrediting McClure, Armstrong effectively asserts a masculine hierarchy that becomes clear during wartime. Men largely answer to other men in times of war, and, therefore, this hierarchal system is important to consider. In Armstrong's statement, it 
becomes clear that by his orders, McClure was only meant to burn the town if it was necessary to defend the fort. However, by claiming that he did not defend Fort George and proceeded to burn the town anyway, he insinuates that he did not follow orders and was thus working outside of government expectations and therein defied the set masculine honourable code of war. This claim is further significant as Armstrong attempted to defend his own honour and thereby his manhood in a similar way that McClure did in his first communication about the burning.

Both McClure and Armstrong's testimonies were largely meant for a very specific, small audience, which makes it important to also consider popular American responses to the burning of Newark. This response becomes clear in evaluating how American newspapers reported on the incident. Generally, one might assume that American newspapers during wartimes would use nationalistic rhetoric that supported one side while clearly opposing the other. However, this was not always the case in reports on the burning of Newark, especially in The War. The War was a newspaper that was published in New York City during the War of 1812. Interestingly, the newspaper aimed to provide an all-encompassing scope of the war, including documents, speeches and letters from British, Canadians, and Americans alike. The 1 February 1813 edition of the paper included an excerpt written by George Prevost, the Governor-in-Chief of British North America at the outbreak of the war and the commander of the forces of North America during the war. In a letter meant for "the inhabitants of his majesty's provinces in North America" he brings up "the miseries which the unfortunate inhabitants of Newark had been made to suffer upon the evacuation of Fort George." ${ }^{, 14} \mathrm{He}$ goes on to condemn the actions of the Americans claiming:

it was certainly matter of just and reasonable expectation, that the humane and liberal course of conduct pursued by his excellency on those different occasions, would have had its due weight on the American government, and would have led it to have abstained ... from any acts of wantonness or violence, which could only tend unnecessarily to add to its ordinary calamities, and to bring down upon their unoffending citizens a retaliation, which, though distant, they must have known would await and certainly follow such conduct. ${ }^{15}$

This is significant as publications discussing subsequent British burnings of Lewiston, Buffalo, and Black Rock were brought up frequently in newspapers - seemingly more so than the burning of Newark. However, they discuss how the British burnings were merely retaliation, a point that will be addressed further in this paper. 
Prevost further goes on to condemn the burning of Newark as it "burned and destroyed the farm house and buildings of many respectable and peaceable inhabitants of the neighbourhood." ${ }^{, 16}$ But most significantly, Prevost directly questions the morality, honour, and masculinity of the American troops as he claims:

It will hardly be credited by those who shall here after read it in the page of history, that in the enlightened era of the $19^{\text {th }}$ century, and in the inclemency of Canadian winter, the troops of a nation calling itself civilized and Christian, had wantonly, and without the shadow of a pretexted, forced 400 helpless women and children to quit their dwellings and to be the mournful spectators of the conflagration and total destruction of all that belonged to them.

This excerpt speaks to the chivalric code cited by Braudy, which suggests that chivalry and honour depended on the protection of the vulnerable female and their defense of civilized virtue $^{17}$; Prevost made clear that he felt that the burning of Newark placed American soldiers outside expectations of masculine honour. Prevost continues to speak to Braudy's nineteenthcentury notions of honour by claiming that the act was "of inhumanity disgraceful [as they] set fire to upwards of 150 houses ... leaving without covering or shelter those 'innocent, unfortunate and distressed inhabitations' whom [McClure], by his proclamation, had previously engaged to protect." Prevost explicitly questioned American soldiers' honour and morality in this letter. Of course, the letter was written for a Canadian audience, but its publication in The War broadened the audience significantly, and therefore this could have been widely read by American consumers.

Nearly two weeks later, the Portsmouth Oracle's 12 February 1814 publication included Mr. Webster's Speech, delivered in the House of Representatives of the United States in January 1814, which suggested a bill to encourage enlistments in the regular army. Interestingly, without directly mentioning the burning of Newark, he implicitly criticized scorched earth warfare. He claimed "It is too true that the frontier is invaded; that the war, with all its horrors, ordinary and extraordinary, is brought within our own territories; and that the inhabitants, near the country of the enemy are compelled to [sic], lighted by the fires of their own homes, or to stay and meet the foe, unprotected by any adequate aid of government" and furthermore attempted to persuade the House that the frontiers needed protecting. ${ }^{18}$ However, the nature of Webster's speech suggests that the burnings of American towns meant that more protection was needed on the frontier, as 
the burning of their homes had provoked British-Canadian troops. This speech is significant as it calls once again for men to enlist into the American army to protect the vulnerable frontier from the British. However, he does not suggest that it was the burning of Newark that caused the British burnings. Although not mentioned by Webster, interestingly the same edition of the Oracle condemned the British for their burnings of American land and homes by claiming that a full British settlement had never been burned except Newark, and it was not even the whole settlement that destroyed there. ${ }^{19}$ The Oracle example equates notions of manly honour with protection, which once again suggests that the burning of Newark defied masculine notions as the Americans left the innocent Newark inhabitants completely defenseless. The Oracle articles furthermore attempt to vilify British acts while simultaneously defending similar American acts which makes the importance of maintaining masculine honour clear.

In order to understand the state in which Americans left Newark on the night of December $10^{\text {th }}$, it is useful to evaluate Newark residents' claims as war losses in the years after the Treaty of Ghent. Evaluating war losses is useful as it underlines the scope of destruction and thereby the extent of the violation of codes of manly honour. In 1812, the Loyal and Patriotic Society of Upper Canada was founded as an association attempting to alleviate distress in Upper Canada caused by the war. In 1817 they published a report with minutes, accounts and other records from 1812-1816. This 400-page document contains hundreds of war loss claims that make direct reference to the burnings at Newark. On 18 February 1814, a meeting of Directors of the Society saw various cases of victims of the burning of Newark. A sample of resolved cases reveals who was displaced and what was lost on December $10^{\text {th }}$.

A resolved case brought to the Society, for example, claimed that fifty dollars be given to Mrs. Hannah Frey who lost her husband to the war, her crops to an encampment of troops and Indians, and her home to enemy fire which "has reduced her to great distress." ${ }^{, 2} \mathrm{~A}$ second resolved case claims that one hundred dollars be given to Mrs. Elizabeth Lawe whose husband served as a Captain in the $1^{\text {st }}$ Regiment of the Lincoln Militia who was wounded and subsequently taken as a prisoner of war when enemies took Fort George. When the Fort was abandoned Mrs. Lawe's home and barn was burnt and she, along with two children, was left without any support during his absence. ${ }^{21}$ A third resolved case granted one hundred dollars to Mrs. Elizabeth McLelan, a widow whose house and barn was burnt which left her with a family of small children with no income to support them. ${ }^{22}$ These three cases support Prevost's claim 
that those most affected by the burning of Newark were women and children. Frey, Lawe, and McLelan all lost their husbands due to the war either by death or capture which already compromised their livelihood and then subsequently lost their homes in December of 1813, leaving them with no way to provide for themselves or their families. These three cases prove once again the burning of Newark challenged understandings of masculine and honourable expectations in war as troops did not protect vulnerable women, but rather their burning of civilian homes effectively displaced the women and children they were meant to protect.

Finally, Elizabeth Campbell's war loss claim ${ }^{23}$ and subsequent request for fuel and candles $^{24}$ exemplify immense loss from which people suffered with the burning of Newark. Her war loss claim outlines everything lost: the house and barn, a walnut dining table, one cow, and calf, thirteen chairs, one four post bedstead, kitchen supplies, etc. Campbell, a widow living in Newark at the time of the burning, claimed $\$ 778.13$ worth of losses directly following the attack. She was defenseless and left to fend for herself in the ensuing winter months. Her desperation was clear, as her request to receive fuel and candles was authorized and ready for distribution in a 19 February 1814 memo. Prevost referred to the barbarity of the Americans displacing women and children out of their homes in the winter months, and Campbell's case exemplifies such hardships faced by inhabitants following the burning of Newark. The Campbell case once again goes against the notion that nineteenth-century honour meant protecting weak females and the defenseless more generally.

In conclusion, the December 1813 burning of Newark in the War of 1812 defied nineteenth-century wartime notions of masculine honour that regulated expectations of soldiers. This defiance is clear as it was expected that men would fight in war for women and protect them from harm and distress, as they were vulnerable and weak. However, the burning of Newark saw American men under George McClure and Joseph Willcocks placing women and children directly in harm's way by burning down the civilian town of Newark when abandoning Fort George. Following the incident, McClure clearly sought to justify his actions in numerous ways. He placed the blame on Secretary of State Armstrong, claimed that they were defending the Fort as the British drew near, and insisted that they gave inhabitants adequate timing to remove themselves and their things from their homes. His justifications suggest that it was imperative that his masculine honour be maintained when questioned. In reality, Armstrong told McClure hat he could burn Newark if, and only if, they were defending the Fort - which was not the case 
as he burnt the town as they were abandoning the Fort, not defending it. The British were not within miles of the Fort when it occurred, but merely abandoning it due to lack of provisions. Finally, Americans gave inhabitants a mere thirty minutes to remove themselves and their families from their homes and seek shelter on a winter's night. Thus, by placing these innocent civilians' lives at risk, including women and children, the American army's departure from Fort George on the night of December $10^{\text {th }}, 1813$ and subsequent burning of Newark effectively challenged wartime expectations of nineteenth-century masculine honour amongst American soldiers during the War of 1812 .

Appendix

Figure I

Elizabeth Campbell's War Loss claim- December 1813

http://images.ourontario.ca/1812/70310/data?n=24

Dwelling House, Barn $£ 600$ s0 2 Pair Tongs and Shovels 22 s0

10 Silver Table Spoons 1001 Pair Dog Irons 20

10 Dessert Spoons 651 Large Iron Oven 15

20 Tea Spoons 5101 Large Wash Kettle 10

1 Silver Soup Ladle 301 Bell Metal Wash Kettle 110

4 Salt \& Mustard Spoons 102 iron Pots, Frying Pan 115

2 Silver Cups, large 1201 Large Copper Tea Kettle 110

1 Chestdrawers 506 Dozen Table Plates 20

13 Chairs

1 Complete Set. 4152 "Dishes

15 Glass Tumblers 3

110

5

Walnut Dining Table 6012 Wine Glasses 14

1 Four Post Bedstead 402 Dressing Glasses 212

1 Travelling " 3101 Piece White Cotton 213

2 Camp " 501 Wrapper Coat 40

1 Small " 201 Barrel Pork 50

1 Washstand 101 " Beef 40

5 Small Tables 2101 Handsome Fowling Piece 50

1 Cow and Calf

1 Mare, two year old, \& yearling 5

3010

0 Tea Tray, 4 doz. Cups and Saucers

2

4

1 Wood Saw, 2 Spades

3 Canadian Stoves 250

$£ 77813$ 


\section{Notes}

${ }^{1}$ Lieut. William MacEwen to Mrs. MacEwen - March 1814 in Lieut.-Col. Cruikshank, The Documentary History of the Campaigns Upon the Niagara Frontier in 1812-14. Vol IX. December 1813-May 1814. Collected and Edited for the Lundy's Lane Historical Society (Welland Tribune Office: 1908), 266.

${ }^{2}$ George Sheppard, Plunder, Profit and Paroles: A Social History of the War of 1812 in Upper Canada (Montreal: McGill-Queen's University Press, 1994), 102.

${ }^{3}$ General Harrison to General George McClure - November 151813 in Lieut.-Col. Cruikshank, The Documentary History of the Campaigns Upon the Niagara Frontier in the Year 1813. Part IV. October to December 1813. Collected and Edited for the Lundy's Lane Historical Society (Welland Tribune Office: 1907), 195.

${ }^{4}$ Sheppard, Plunder, Profit, Paroles, 102-3.

${ }^{5}$ Robin Fabel, "The Laws of War in the War of 1812 Conflict," Journal of American Studies 14, no. 2 (August 1980): 201.

${ }^{6}$ Ibid., 204.

${ }^{7}$ Ibid., 205.

${ }^{8}$ Leo Braudy, From Chivalry to Terrorism: War and the Changing Nature of Masculinity (New York: Alfred A. Knopf, 2003), 283.

${ }^{9}$ Stephen Miles, "Wanted," The Kingston Gazette, January 2, 1813.

${ }^{10}$ Brig.-Gen. McClure, "Excerpts from Letters Dated Dec. 10 and 13," The War, May 31, 1814.

${ }^{11}$ General McClure to the Public in Cruikshank Vol IX, 48-50.

12 Sheppard, Plunder, Profit and Parole, 102-3.

${ }^{13}$ The Secretary of War to Governor Hopkins, December $26^{\text {th }} 1813$ in Cruikshank Vol IX, 54.

${ }^{14}$ George Prevost, "From Canada," The War, February 1, 1814.

${ }^{15}$ Ibid.

${ }^{16}$ Ibid.

${ }^{17}$ Braudy, Chivalry to Terrorism, 283.

${ }^{18}$ Charles Turrell, "Mr. Webster's Speech," Portsmouth Oracle, February 12, 1814.

${ }^{19}$ Ibid.

${ }^{20}$ William Gray, The Report of the Loyal and Patriotic Society of Upper Canada (Montreal, Lower

Canada. 1817), 101.

${ }^{21}$ Ibid., 101.

22 Ibid., 102.

${ }^{23}$ See Appendix Figure I

24 "Memo Authorizing a Ration of Fuel and Candles" to Mrs. Elizabeth Campbell, February 19, 1814. http://images.ourontario.ca/1812/70297/data?n=12 